\title{
Dilemmas and Challenges in Treating Seronegative Autoimmune Encephalitis in Indian Children
}

\author{
Bandya Sahoo, Mukesh Kumar Jain, Reshmi Mishra, Sibabratta Patnaik \\ Department of Pediatrics, Kalinga Institute of Medical Sciences, Bhubaneswar, Odisha, India
}

\section{Abstract}

Objective: The main objective is to assess the challenges in diagnosis and treatment while managing seronegative cases of autoimmune encephalitis (AIE) in Indian children. Methods: A cohort study of patients with AIE was done where clinical presentations, investigations, management were analyzed and these patients were followed up to assess the evolution of the disease. Results: Nine patients were included in the study. Four patients presented with super-refractory status epilepticus (SRSE). Other presentations were behavioral change, hemiplegia, and autonomic dysfunction. Initial magnetic resonance imaging brain was suggestive of AIE in two patients. Only two were seropositive for cerebrospinal fluid (CSF) autoimmune panel. Five patients responded to the first-line immunotherapy and four required the second-line immunotherapy. Conclusion: The possibility of autoimmune encephalitis should be considered in patients with super-refractory status epilepticus. A large proportion of children with suspected AE may be "seronegative." A trial of immunotherapy should be given to these children when there is a strong clinical suspicion of autoimmune encephalitis even in the absence of cerebrospinal fluid autoantibodies.

Keywords: Autoimmune encephalitis, children, clinical clues, seronegative

\section{INTRODUCTION}

Autoimmune encephalitis (AIE) is a difficult clinical diagnosis as the clinical imaging and laboratory findings mimic many forms of autoimmune and infectious encephalitis. ${ }^{[1]}$ These noninfectious causes of encephalitis are a diagnostic priority as they are treatable if diagnosed early and delay in treatment can be life-threatening. They can be associated with an underlying malignancy or systemic disease. A careful history and examination may give early clinical clues such as cognitive disturbances, mood/ personality changes, memory deficits, seizures, dyskinesia, and movement disorders. With the advances in molecular diagnostics, new immunological markers (antibodies) are being discovered which can be helpful in early diagnosis of these patients. However, obtaining autoantibodies in resource-poor settings may not be feasible therefore it might be prudent to start immunotherapy based on the clinical clues after exclusion of infectious etiologies of encephalitis. This is of paramount importance as failure to appropriately diagnose and delay in treatment can lead to irreversible brain damage.

Considering the fact that noninfectious etiology specifically, autoimmune phenomena are being increasingly recognized as

\begin{tabular}{|l|l|}
\hline \multicolumn{3}{|c|}{ Access this article online } \\
\hline Quick Response Code: & Website: \\
\hline & www.ijccm.org \\
\hline & \\
\hline
\end{tabular}

causes of encephalitis, ${ }^{[2]}$ this article aims at early recognition and treatment of these children even in the absence of autoantibodies.

\section{Methods}

This prospective study included children under 18 years with clinical evidence of probable AIE who were admitted to a tertiary care referral hospital. Patients with clinical evidence of encephalitis with neuropsychiatric symptoms, abnormal behavior, movement disorders, irritability, and refractory seizures were included. Patients with laboratory evidence of infectious encephalitis were excluded from the study.

The demographic data and clinical characteristics of all these patients were analyzed. Investigations done included routine complete blood count, serum electrolytes, renal function test, liver function test, thyroid function test,

Address for correspondence: Dr. Bandya Sahoo Department of Pediatrics, Kalinga Institute of Medical Sciences, Bhubaneswar - 751 015, Odisha, India. E-mail: bandyasahoo@gmail.com

This is an open access journal, and articles are distributed under the terms of the Creative Commons Attribution-NonCommercial-ShareAlike 4.0 License, which allows others to remix, tweak, and build upon the work non-commercially, as long as appropriate credit is given and the new creations are licensed under the identical terms.

For reprints contact: reprints@medknow.com

How to cite this article: Sahoo B, Jain MK, Mishra R, Patnaik S. Dilemmas and challenges in treating seronegative autoimmune encephalitis in Indian children. Indian J Crit Care Med 2018;22:875-8. 
and HIV antibody. Tests done to exclude infectious and metabolic encephalopathies included dengue, rickettsia, mycoplasma serology, and serum ammonia and lactate. Cerebrospinal fluid (CSF) analysis included viral studies and autoimmune panel (N-methyl-D-aspartate [NMDA], AMPA 1 and 2, CASPR 2/VGKC, LGI-1, GABA B1, B2) by indirect immunofluorescence assay. Antinuclear antibodies and anti-dsDNA was done to rule out vasculitis. Electroencephalography (EEG) and magnetic resonance imaging (MRI) brain were done in all patients. Computed tomography (CT) abdomen was done in female patients to look for ovarian teratoma.

\section{RESULTS}

Nine patients of suspected AIE were included in the study, of which four were female. Three of them were toddlers. The most common presentation was behavioral change (4 patients) and super-refractory status epilepticus (SRSE) (4 patients). One patient each presented with hemiparesis and behavioral changes. All patients had seizures requiring multiple antiepileptic drugs. Four out of nine had movement disorders, especially orofacial dyskinetic movements and autonomic disturbances. Four patients required mechanical ventilation due to refractory seizures.

Baseline hematological and biochemical workup was normal. CSF showed lymphocytic pleocytosis in three patients. CSF autoimmune panel was positive for two patients with NMDA receptor (NMDAR) antibody in one patient and VGKC antibody in another patient [Table 1]. MRI was abnormal in two patient showing T2 hyperintense lesions in the bilateral temporal area. EEG showed background slowing in patients with status epilepticus on thiopental drip. CT abdomen, antithyroid antibodies, and vasculitis workup done were normal for all patients.

All patients except one received methylprednisolone (30 mg/kg/day for 5 days) and intravenous immunoglobulin (IVIg) $(0.4 \mathrm{~g} / \mathrm{kg} /$ day for 5 days). Seizures were managed with antiepileptic drugs. Patients with SRSE required thiopental drip and ketogenic diet for control of seizures. Behavioral problem was managed with antipsychotic drugs. The duration of hospital stay ranged from 14 days to 60 days. All patients were advised for pulse methylprednisolone therapy at discharge.

All patients have shown significant improvement clinically and only the first patient has regained the baseline cognitive and functional status. During follow-up, four patients had recurrence of symptoms with seizures and behavioral problems.

\section{Discussion}

Seronegative AIE is a subgroup of AIE cases with negative serologic tests for autoantibodies. Children presenting with AIE syndrome are a diagnostic challenge because although criteria and guidelines for the clinical diagnosis of AIE in adults have recently been developed, there are no consensus definitions for pediatric-specific seronegative AIE. Previously cited as rare, recent literature shows that autoimmune factors may account for a majority of the nonviral encephalitis. ${ }^{[2]}$ Considering the fact that noninfectious etiology specifically, autoimmune phenomena are being increasingly recognized as causes of encephalitis, ${ }^{[3]}$ the therapeutic challenges that clinicians face such as diagnosis of cases with negative antibody test, the timing of therapy, and the role of second-line therapy is of paramount importance. Appropriate autoantibody testing done along with exclusion of infectious causes confirms specific diagnoses. However, overdependence on antibody testing may delay diagnosis as it is not readily accessible and results can take weeks. Furthermore, the absence of autoantibodies does not exclude the possibility of AIE as the positive rate is only $8.6 \%{ }^{[4]}$

There are very few studies of AIE in children reported from India $^{[5,6]}$ and this is the first clinical series of seronegative AIE. Antibody-negative AIE behaves similarly in the initial clinical presentation, response to immunotherapy and long-term outcome. Therefore, a strong clinical suspicion is a key to diagnosis of seronegative AIE. The demographic data of our study showed a male: female ratio of $1.2: 1$ which is in contrast to the female predominance showed by Kamble et al..$^{[7]}$ Most common early symptoms in children have been described as abnormal behavior and seizure in some earlier studies ${ }^{[8]}$ which were also found in our cohort. Autonomic manifestations include hyperthermia, tachycardia, hypersalivation, and hypertension which was seen in four of our patients. This is in contrast to the study done in South Indian children by Sudan et al. MRI brain done in the initial period of illness was normal in most of the patients except two patients. Repeat MRI brain showed T2 hyperintensity in the bilateral temporal region in one child. This emphasizes the fact that MRI brain may be normal in most patients with AIE. EEG was also normal in most patients except those with SRSE who had generalized epileptiform activity.

CSF finding may show moderate lymphocytic pleocytosis, mildly increased protein with oligoclonal bands. Three of our patients had lymphocytic pleocytosis and none had raised protein or oligoclonal bands. CSF autoimmune panel test done by immunofluorescence assay was positive for only two patients (one patient was positive for NMDAR antibody and another for VGKC) although all patients responded to immunotherapy. This emphasizes the fact that antibody test may be negative even in the presence of AIE. Some explanations for negative antibodies tests are false-negative results caused by a small amount of antibodies and the presence of T-cell-dominant AIE. The existence of antibody-negative AIE was supported by the finding that $44 \%$ of patients that are rituximab responders have AIE without detectable antibodies.

The mainstay of treatment in AIE is immunomodulation. The first-line therapy is high-dose steroid (intravenous [IV] methylprednisolone), followed by IVIg or plasma exchange. Since early application of immunotherapy is essential to 


\begin{tabular}{|c|c|c|c|c|c|c|c|c|c|}
\hline Cases & Age/sex & Clinical presentation & CSF & $\begin{array}{l}\text { CSF } \\
\text { autoimmune } \\
\text { panel }\end{array}$ & EEG & MRI brain & $\begin{array}{l}\text { Immunotherapy } \\
\text { given }\end{array}$ & $\begin{array}{l}\text { Duration } \\
\text { of stay }\end{array}$ & Follow-up \\
\hline 1 & $\begin{array}{l}\text { years/ } \\
\text { female }\end{array}$ & $\begin{array}{l}\text { Seizure, hyponatremia, } \\
\text { insomnia, burning } \\
\text { sensation of hand and } \\
\text { feet }\end{array}$ & & Negative & $\mathrm{N}$ & $\mathrm{N}$ & $\begin{array}{l}\text { Methylprednisolone, } \\
\text { IVIg }\end{array}$ & 22 days & 28 months \\
\hline 2 & $\begin{array}{l}7 \text { years/ } \\
\text { female }\end{array}$ & $\begin{array}{l}\text { Detoriation of speech, } \\
\text { handwriting, seizure, } \\
\text { behavioral problem }\end{array}$ & $\mathrm{N}$ & Negative & $\mathrm{N}$ & $\mathrm{N}$ & $\begin{array}{l}\text { Methylprednisolone, } \\
\text { plasmapheresis, } \\
\text { IVIg }\end{array}$ & 28 days & 32 months \\
\hline 3 & $\begin{array}{l}7 \text { years/ } \\
\text { female }\end{array}$ & SRSE & $\begin{array}{l}\text { Cells - } 9 \\
\text { L - } 90 \%\end{array}$ & Negative & $\begin{array}{l}\text { Generalized } \\
\text { seizure activity }\end{array}$ & $\mathrm{N}$ & $\begin{array}{l}\text { Methylprednisolone, } \\
\text { IVIg, rituximab }\end{array}$ & 45 days & 8 months \\
\hline 4 & $\begin{array}{l}3 \text { years/ } \\
\text { male }\end{array}$ & SRSE & $\mathrm{N}$ & Negative & $\begin{array}{l}\text { Generalized } \\
\text { seizure activity }\end{array}$ & $\mathrm{N}$ & $\begin{array}{l}\text { Methylprednisolone, } \\
\text { IVIg, rituximab }\end{array}$ & 59 days & 6 months \\
\hline 5 & $\begin{array}{l}8 \text { years/ } \\
\text { male }\end{array}$ & $\begin{array}{l}\text { Focal seizure, altered } \\
\text { behavior, restlessness }\end{array}$ & Cells - 4 & $\begin{array}{l}\text { VGKC/CASPR2 } \\
\text { positive }\end{array}$ & $\mathrm{N}$ & $\mathrm{N}$ & $\begin{array}{l}\text { Methylprednisolone, } \\
\text { IVIg }\end{array}$ & 22 days & 5 months \\
\hline 6 & $\begin{array}{l}2 \text { years/ } \\
\text { female }\end{array}$ & $\begin{array}{l}\text { Focal seizure, } \\
\text { hemiparesis, abnormal } \\
\text { movement }\end{array}$ & $\begin{array}{l}\text { Cells - } 32 \\
\mathrm{~L}-100 \%\end{array}$ & NMDA positive & $\mathrm{N}$ & $\mathrm{N}$ & $\begin{array}{l}\text { Methylprednisolone, } \\
\text { IVIg, rituximab }\end{array}$ & 42 days & 4 months \\
\hline 7 & $\begin{array}{l}7 \text { years/ } \\
\text { male }\end{array}$ & $\begin{array}{l}\text { Generalized seizure, } \\
\text { abnormal behavior }\end{array}$ & $\mathrm{N}$ & Negative & $\mathrm{N}$ & $\mathrm{N}$ & Methylprednisolone & 14 days & 2 months \\
\hline 8 & $\begin{array}{l}1 \text { years/ } \\
\text { male }\end{array}$ & SRSE & $\mathrm{N}$ & Negative & Theta activity & $\begin{array}{l}\text { Hyperintensity in } \\
\text { bilateral temporal area }\end{array}$ & $\begin{array}{l}\text { Methylprednisolone, } \\
\text { IVIg, rituximab }\end{array}$ & 60 days & $\begin{array}{l}\text { At present } \\
\text { in PICU }\end{array}$ \\
\hline 9 & $\begin{array}{l}12 \text { years/ } \\
\text { male }\end{array}$ & SRSE & Cells - 38 & Negative & $\begin{array}{l}\text { Generalized } \\
\text { seizure activity }\end{array}$ & $\begin{array}{l}\text { Hyperintensity in } \\
\text { bilateral caudate, basal } \\
\text { ganglia, thalamus }\end{array}$ & IVIg & 15 days & $\begin{array}{l}\text { At present } \\
\text { in PICU }\end{array}$ \\
\hline
\end{tabular}

IVIg: Intravenous immunoglobulin; PICU: Pediatric intensive care unit; CSF: Cerebrospinal fluid; EEG: Electroencephalography;

NMDA: N-methyl-D-aspartate; MRI: Magnetic resonance imaging; Super-refractory status epilepticus; N: Normal

prevent irreversible brain damage, a strong clinical suspicion based on clinical clues was helpful in the present study to start treatment even in the absence of positive antibody test. Four patients were refractory to the first-line treatment in the present study and required rituximab. Patients with AIE present with variable clinical manifestations, severity, comorbidity status and immunotherapy responsiveness, and therefore the timing of initiation of therapy and starting of the second-line therapy was individualized in our patients. Recovery is a gradual process as seen in our cohort. Patients responding to the first-line therapy recovered in weeks but those requiring second-line therapies responded only after a month.

AIE is not a monophasic illness and relapse has been noted even after $5-10$ years. $^{[9]}$ The rate of relapse varies from $10 \%$ to $20 \%$ depending on the type of antibody. In the present study, three patients had relapse required intermittent therapy of IV methylprednisolone. Early aggressive therapy reduces relapse rates ${ }^{[10]}$ Maintenance therapy is usually considered in clinical practice in order to maximize therapeutic gain, attain the highest functional state possible, as well as to make certain that the patient reaches complete remission. In our study, all patients received maintenance therapy with monthly pulse dose of methylprednisolone and duration of the therapy was individualized depending on the severity of the disease. None of them required intermittent administration of rituximab as there was significant clinical improvement weekly therapy.

Follow-up of a large series of NMDAR antibody-positive patients showed recovery in $75 \%$ of patients with mild sequelae. In our study, two patients completed 2 years of follow-up and three of them had readmission with recurrence of symptoms. All patients in the present study recovered with mild-to-moderate disability including NMDAR-positive patient. This can be attributed to various factors such as severity of the patients and timing of starting immunotherapy.

\section{Conclusion}

Although the detection of auto-antibodies is a confirmatory diagnostic test, about half of all autoimmune encephalitis series are antibody negative. Therefore, a strong clinical suspicion is essential for diagnosis. Efforts aiming at detecting new autoantibodies and pediatric-specific consensus definitions for seronegative autoimmune encephalitis could help in management of these patients. In the absence of enough evidence, the current therapeutic approach should be pragmatic rather than evidence-based. Thus, timing of second-line therapy and duration of maintenance therapy should be individualized.

\section{Financial support and sponsorship}

Nil.

\section{Conflicts of interest}

There are no conflicts of interest.

\section{RefEREnCES}

1. Ahmad SA, Archer HA, Rice CM, Gerhand S, Bradley M, Wilkins A, et al. Seronegative limbic encephalitis: Case report, literature review and proposed treatment algorithm. Pract Neurol 2011;11:355-61. 
2. Gable MS, Sheriff H, Dalmau J, Tilley DH, Glaser CA. The frequency of autoimmune $\mathrm{N}$-methyl-D-aspartate receptor encephalitis surpasses that of individual viral etiologies in young individuals enrolled in the California encephalitis project. Clin Infect Dis 2012;54:899-904.

3. Granerod J, Ambrose HE, Davies NW, Clewley JP, Walsh AL, Morgan D, et al. Causes of encephalitis and differences in their clinical presentations in England: A multicentre, population-based prospective study. Lancet Infect Dis 2010;10:835-44.

4. Lee SK, Lee ST. The laboratory diagnosis of autoimmune encephalitis. J Epilepsy Res 2016;6:45-50.

5. Chakrabarty B, Tripathi M, Gulati S, Yoganathan S, Pandit AK, Sinha A, et al. Pediatric anti-N-methyl-D-aspartate (NMDA) receptor encephalitis: Experience of a tertiary care teaching center from North India. J Child Neurol 2014;29:1453-9.
6. Sudan YS, Vinayan KP, Roy AG, Wagh A, Kannoth S, Patil S, et al. Clinical characteristics and follow-up of South Indian children with autoimmune encephalopathy. Indian J Pediatr 2016;83:1367-73.

7. Kamble N, Netravathi M, Saini J, Mahadevan A, Yadav R, Nalini A, et al. Clinical and imaging characteristics of 16 patients with autoimmune neuronal synaptic encephalitis. Neurol India 2015;63:687-96.

8. Florance NR, Davis RL, Lam C, Szperka C, Zhou L, Ahmad S, et al. Anti-N-methyl-D-aspartate receptor (NMDAR) encephalitis in children and adolescents. Ann Neurol 2009;66:11-8.

9. Ariño H, Armangué T, Petit-Pedrol M, Sabater L, Martinez-Hernandez E, Hara M, et al. Anti-LGI1-associated cognitive impairment: Presentation and long-term outcome. Neurology 2016;87:759-65.

10. Nosadini M, Mohammad SS, Ramanathan S, Brilot F, Dale RC. Immune therapy in autoimmune encephalitis: A systematic review. Expert Rev Neurother 2015;15:1391-419. 